\title{
Awakening, or Watchfulness: Naum Faiq and Syriac Language Poetry at the Fall of the Ottoman Empire
}

\author{
Robert Isaf
}

From the Hindu Kush to the Brecon Beacons, the rise of nationalistic feelings in the early twentieth century was accompanied by an outpouring in nationalistic literature. This was also the case among the Syriac-language communities of the Middle East, who wrote in what linguists call Aramaic. This language is attested in the tenth century BC in today's northern Syria, and in the second and early third centuries $\mathrm{AD}$ became the primary medium for literary expression around Edessa, Urfa in today's southeastern Turkey. This specific form of Aramaic is referred to in English as Classical Syriac, and its importance as a literary language for various forms of Syriac Christianity (in today's Maronite Church, Syriac Orthodox Church and Church of the East, and their Roman Catholic counterparts) has contributed to its survival, even as it ceased to be spoken outside learned circles. The Syriac-language poetry we will be examining in this paper was written in that Classical Syriac dialect, taught to its practitioners in school and not in the home, and was allied with a sense of nationalism associated with a perceived ethnic connection to the ancient Assyrian empire. The literary movement therefore could be styled, following earlier authors, as an "Assyrian Awakening."1

The poetry produced by this movement during the waning years of the Ottoman Empire is a valuable witness for the study of contemporaneous minority nationalisms. Our exploration of the content, craft, and tradition of this poetry serves to demonstrate the relationship of nascent Syriac-language nationalism to contemporary Arabic-language nationalism and nationalist poetry, and to show the importance of Classical Syriac as a poetic medium in the further development of an Assyrian national identity. First, I hope to show that, although the political impulse towards a particular Assyrian nationalism was part of a contemporaneous movement widespread throughout the Ottoman Empire in the 1910s, and at least partially an offshoot of the more developed

1 See for instance Adam H. Becker, Revival and Awakening: American Evangelical Missionaries in Iran and the Origins of Assyrian Nationalism (Chicago: University of Chicago Press, 2015), and Baarda, this volume. 
nationalist tradition of Eastern Syriac communities (especially those in the Persian Urmia region), its literature emerged in its given form from the initiators' readings of and familiarity with the "Arab Awakening" - the Arab Nahda and specifically the writers of the previous generation. ${ }^{2}$ Alternatively, it could be said that the particulars of the Assyrian Awakening movement in some noteworthy ways echo the first phases of the Arab Nahda - whereas in other ways the time frame and environment of the movement are better understood as overlapping with a later phase of Nahda literature.

With an understanding of that historical framework we can examine more closely how writers of the Assyrian Awakening attempt to revive the Classical Syriac tradition, and the ways in which their nationalist literature relates to nationalist literatures around it. The poetry is distinguished from earlier Classical Syriac verse in that it often deals with secular instead of religious themes sometimes even appearing pointedly non-religious, focusing on an Assyrian ethnos rather than a Syriac religion. It is often a social and historical past that we encounter in this poetry, a civic law rather than a religious law, gentile cities of pagan temples rather than monasteries. Despite drawing inspiration from immediate Arabic predecessors, the actual poetic technique has not been adapted from contemporary Arabic practice but consciously drawn from the older Syriac tradition, especially the stage to which it had developed in the so-called Syriac Renaissance (a tradition which, itself, owes much to earlier Persian and Arabic influences). ${ }^{3}$ We will further find that all of the poems dealt with here have a clear purpose. In one way or another the poems attempt to instil in their readers a particular sense of secular, ethnic unity, of pride, and of both protective and positive action for the good of the "Assyrian" people.

Finally, specifically in the work of the Syriac Orthodox nationalist Naum Faiq, who is the focus of this paper, we find that this poetry illustrates the central role of Classical Syriac in the ever more important self-designated "Assyrian" identity. Not only is the use of Classical Syriac as the language of this nationalist poetry important; the poetry itself emphasizes time and again the centrality of Classical Syriac to the national cause, both as an immaterial inheritance and as a discipline that must be studied, diligently, in order for individual members of the nation and for the nation as a whole to achieve parity with the other peoples of the earth and attain the greatness and glory

2 See for instance Stephen Sheehi, "Towards a Critical Theory of al-Nahdah: Epistemology, Ideology and Capital," in Journal of Arabic Literature 43 (Leiden: Brill, 2012), 269-298.

3 For more information on the history of Syriac literature, see especially Anton Baumstark, Geschichte der syrischen Literatur (Bonn: A Marcus \& E. Webers Verlag, 1922), and Alessandro Mengozzi, Religious Poetry in Vernacular Syriac from Northern Iraq (17th-2oth Centuries): An Anthology (csco 628; Leuven: E. Peeters, 2011). 
that, in the pseudo-historical imagination of Assyrian nationalists, it had in biblical days. ${ }^{4}$

Naum Faiq (Na"ūm Fāiiq) was born in 1868, in the city of Diyarbekir, at that time a hub of the Empire's Syriac-tradition community, and a hub, therefore, for budding nationalistic sentiments within that community. ${ }^{5}$ The city had played a unique role in Syriac affairs over the previous three centuries as the seat of a number of break-away patriarchs from the Church of the East, but also home to the considerable Syriac Orthodox community into which Faiq was born. The movements associated with the Roman-aligned patriarchs became known as Chaldean, after the ancient people with its capital at Babylon, and both exemplified and accelerated the growing influence of Western missionaries in the non-Latin Christian communities of the Middle East. The presence of these Western missionaries contributed to the continuation of the tradition of Syriac literary production from the sixteenth all the way through to the nineteenth century. The first breakaway patriarch allied himself with the Roman church in 1551; a few decades later a roughly 150-year period began of increased literary production in Syriac, from the 1590 s to the 1740 s, both in local vernaculars and in Classical Syriac. ${ }^{6}$

4 On Syriac Christians in Diyarbekir, see Emrullah Akgunduz, "Some Notes on the Syriac Christians of Diyarbekir in the Late Nineteenth Century: A Preliminary Investigation of Some Primary Sources," in Social Relations in Ottoman Diyarbekir, 1870-1915, edited by Joost Jongerden and Jelle Verheij (Leiden: Brill, 2012) and Khalid Dinno, The Syrian Orthodox Christians in the Late Ottoman Period and Beyond (Piscataway, Gorgias Press, 2017). It should be quickly noted at this point that, although there was a backlash in later generations (and even among poets writing in Classical Syriac) against 'Assyrianism' of this sort, or the expressed belief that the Syriac churches were unified by an ethnic Assyrian heritage, in Faiq's own time there was no virulent controversy associated with that claim. Therefore, questions of the 'legitimacy' of the Assyrianist worldview expressed by Faiq and his contemporaries lie outside the scope of this paper; see again Becker, Revival.

5 See Naures Atto, Hostages in the Homeland, Orphans in the Diaspora: Identity Discourses Among the Assyrian/Syriac Elites in the European Diaspora (Leiden: Leiden University Press, 2011), 263-297. See also the entries on Naum Faiq in Rudolf Macúch, Geschichte der spät-und neusyrischen Literatur (Piscataway: Gorgias Press, 2009), and George A. Kiraz, "Fāiq, Na"ūm: Naoum Elias Palak (ca. 1868-1930) [Syr. Orth]," Gorgias Encyclopedic Dictionary of the Syriac Heritage (Piscataway NJ: Gorgias Press 2011), 163.

6 Heleen Murre-van den Berg, Scribes and Scriptures: The Church of the East in the Eastern Ottoman Provinces (1500-1850) (Leuven: Peeters, 2015). 
With the initiation in the 1830 s of Protestant missionary activity among Church of the East communities in Iran, a new wave of literary production began, this time predominantly in the vernacular of the Urmia region. During the following decade, at the same time that the first Protestant Syriac-type printing press arrived in Urmia, excavation of the ancient Assyrian capital of Nineveh began, under Englishman Henry Layard, with the Westerners employing the term "Assyrian" to describe the Christians among whom they were working. The designation probably began life among Westerners using it for the Church of the East (also called 'Nestorians'), which was treated in much of the orientalist imagination as a nation in itself. ${ }^{7}$ An American Protestant "Assyria Mission" was established in Mosul in 1849; by 1886 the third successive Anglican mission to the region was initiated, "to the Assyrian Christians," which forbade the wearing of anything except traditional dress in its schools and actively worked to encourage a sense of pride among pupils in their own culture. ${ }^{8}$

Despite the decades-long tradition of "Assyrian" as a label, it was only closer to the turn of the century that this new nationalism began to call itself "Assyrian" in turn. ${ }^{9}$ As Becker concludes, the missionary schools played an essential, and intentional, role in fermenting a national identity among their pupils based on their distinct linguistic, literary, religious, and cultural traditions. ${ }^{10}$ These developments in Iran could not fail to influence the attitudes of the Syriac speakers in Ottoman territory, and despite differences - sectarian and dialectical, for instance - a sense of a shared ethnic identity among Christians of the Syriac tradition developed.

In 1879 an organization calling itself the Ancient Suryani Brotherhood (Süryani Kadim Kardesligi, in Turkish) was founded in Diyarbekir. It proceeded to found a grammar school oriented towards the teaching of Classical Syriac, the first of its kind; it was here that Faiq received his education, under the directorship of an early and notable proponent of the Assyrian nationalist ideology, Hanna Sirri Ceqqi. ${ }^{11}$ In 1888, Faiq himself began teaching. Although the grammar school was forced to close in 1890, its decade of education left an immense

\footnotetext{
7 Becker, Revival, 237. Becker cites mention at least as early as 1848 of the "Nestorian nation."

8 See Heleen Murre-van den Berg, From a Spoken to a Written Language: The Introduction and Development of Literary Urmia Aramaic in the Nineteenth Century (Leiden: Nederlands Instituut voor het Nabije Oosten, 1999) and J.F. Coakley, The Church of the East and the Church of England: A History of the Archbishop of Canterbury's Assyrian Mission (Oxford: Clarendon Press, 1992).

$9 \quad$ Becker, Revival, 257.

$10 \quad$ Ibid., 262.

11 Atto, Hostages, 272.
} 
impact on the Syriac-speaking community world-wide, Faiq being perhaps its greatest representative. He went on to teach at a variety of other Syriac schools in the region, ${ }^{12}$ and was still teaching in 1909 , when, along with a number of friends, he co-founded a literary society called al-Intibäh, an Ottoman Turkish loan from Arabic meaning "The Awakedness," irutho in Syriac. ${ }^{13}$

It was in this context that Faiq's most well-known poem was written (see the Appendix at the end of this chapter for the Syriac text of all poems; this is Poem 1):

\author{
Awaken, son of Assyria, awaken!, \\ And see how enlightened the world is. \\ The opportunity is being driven, lo, from our hands, \\ And time too swiftly sweeps away. \\ Awaken, son of Assyria, awaken!
}

Let refuge be taken in in wakefulness.

Let us twist in flight to exaltation.

If we do not awaken there shall be no hope.

Misfortune befalls us on our path.

Awaken, son of Assyria, awaken! ${ }^{14}$

The society seems to have spawned at least two journals, one of the same name (al-Intibāh), which began publication that same year in the United States, and one under Faiq's own editorship, in Diyarbekir. ${ }^{15}$ This second journal, which began publication in 1910, was Kawkab Madenho, Syriac for Star of the East, very likely in reference to an important contemporaneous paper founded in Urmia, in 1906, called simply The Star. ${ }^{16}$ The Star and its circle of contributors was itself closely associated with early attempts at nationalist organization (within Iran), specifically the foundation of a consciously ecumenical "National Union" in 1907 and a somewhat more clandestine "Syrian Union" in

12 Kiraz, "Fā’iq, Na“"ūm," 163.

13 Ibid., 163. Please note that throughout the course of this paper I will use whichever valid English translation of this single Syriac word - which, as shall be seen, appears quite frequently - seems most appropriate and coherent within the English context and syntax. In different circumstances "awakedness," "awakening," or "watchfulness" may be more or less serviceable English renderings.

14 All translations from Syriac verse are mine, and tend towards the literal. The original Syriac of this poem is included at the end of the paper, along with the original texts of all other poems in the order in which they are introduced below.

15 Atto, Hostages, 273.

16 Becker, Revival, 290. 
1908. Adam Becker cites The Star as reporting on the young nationalists who had been "awakened" to the national plight during meetings at the home of the Urmia intellectual and writer Isaac Malek Yonan. ${ }^{17}$ It was in his own Star of the East that Faiq published his polemical poem of "awakening," written to inaugurate his "awoken" and "watchful" literary/political society. Publication allowed the poem to spread and become a kind of anthem for the nascent nationalistic sentiments of Assyrians both in their ancient homeland and abroad. Only three years later Faiq himself took the path to exile, fleeing government persecution to relocate in New Jersey, where many of his coreligionists from Diyarbekir had already begun new lives following the massacres of $1895^{18}$

Faiq contributed to al-Intibāh for his first few years in America, publishing another journal, called Beth Nahrin (the Syriac name for Mesopotamia), in January 1916. ${ }^{19}$ The very first poem published in this new journal, attributed to a man named Sharko Ahro (otherwise unknown), appeared on the front page of Beth Nahrin's second issue, underlining Faiq's staunch nationalist inspirations (Poem 2 in the Appendix).

Someone give me wings that I can fly to Bethnahrin

And see my imprisoned Assyrian brothers wherever they are scattered

Those who were in this world suns and moons

And in their destruction are extinguished lamps and darkened lights

Oh, if only I had wings to fly to that foreign country,

That I could go and dwell upon the heights and the mountains of Persia

And I would visit them, the sons of our nation, to outrage them

Nor have the sons of vipers yet sheathed the sword of savages.

O sons of our nation, oh, we are shattered at your torment.

And by your deaths, oh, we are forsaken like those deceased.

If here we are delivered from the dagger of Beelzebub

Yet we are battered by the desolation of your flesh and spirit.

It seems to our eyes night and day will never end.

Everyone near and far alike depends on you.

Nevermore shall our hearts fill with feasting and rejoicing

Until your bitter distances are united with ours.

17 Ibid., 287.

18 Dinno, The Syrian Orthodox, 244.

19 Kiraz, "Fā’iq, Na"ūm," 163. 
According to George Kiraz, Faiq published a collection of national anthems in Diyarbekir, in 1908, which he then reissued in 1913 in New Jersey. ${ }^{20}$ This appears to have been the only full-sized collection of poetry he produced, and included work not only in Syriac but also in Turkish and Arabic. ${ }^{21}$ Although neither of these printings is available to the current author at this time, we can consult an item that appears to be a third reprint of the same collection, imprinted in Patterson, New Jersey, and dated $1917 .{ }^{22}$ Evidently hand-copied, and titled The Book of Anthems for Wakefulness, or - National and Motherland Songs (the title given in both Syriac and Turkish), it is 82 pages long, with the majority of poems being "songs" (labeled as nashirhalar) in Ottoman Turkish Garshuni, although Arabic Garshuni makes up a significant section as well. The manuscript itself is presented as a Turkish document, that being the language used to introduce the volume and to label the four sections. The last of these is "Assorted Poems" - the second and third "Turkish Songs" and "Arabic Songs," respectively. The first section is titled "Syriac Songs," although even then the title is given in Turkish Garshuni.

The manuscript as a whole deserves more attention, but for our purposes now it is this first section that is of the most interest. The shortest, it is composed of four poems in Classical Syriac, each given with indications of the music or metre to which they have been written. The first three are undated, and can reasonably be assumed to have been written before 1908, when Faiq's first national anthems were published in Diyarbekir, since throughout the manuscript poems written after that first edition all seem to have an indication of their date and place of composition - as is the case, for instance, with the final poem in this section.

The first poem is written in the "Serughian" or "Jacobian" metre (referring to the Syriac Orthodox poet Jacob of Serugh), which is composed of 12 syllables per line divided into three equal feet (often in context called pausae). Its title is given as "A Plea and a Rousing Cry" (Poem 3 of the Appendix). It consists of seven quatrains in monorhyme, and as literature stands out clearly as Faiq's best poem thus far. Stanzas 3 through 5 form the highlight:

20 Ibid. See Beth Nahrin March 15, 1916 (available at the MARA database: www.Assyrian Archive.org).

21 Macúch, Geschichte, 433.

22 A digitized copy of the manuscript is in the possession of Johny Messo, acting President of the World Council of Arameans, who took the initiative to pass a copy on to me; for which, needless to say, I am immensely grateful. 
Beloved brothers, look, the apothecary is opened to you.

Go take up your medicines, seek succour for your sickness.

For if you fail to fill your drinking skins today with water,

What will you drink when you walk the parched places?

Where is our beauty, where is our opulence, O Sons of Aram?

You are all now lost, and we deprived of our great dignity.

Come, let us all gather together, and beg healing for our illness -

With the strength of our Lord shall we resurrect our dead Nation.

Oh Suryoye, stinking in the grave like Lazarus,

Rise, for Christ cried out "Awake, and there shall be hope for you."

Be diligent as you study the teachings of the first who passed -

They shall shine a light for you like the light of daybreak. ${ }^{23}$

The second and third poems are shorter - the second is entitled simply "Wakefulness" ('irutho), and the third, "Assyrians" (Othuroye). They will be quoted in full in the next section. The last poem has in its title the only example of Latin lettering in the manuscript: it reads "My Country 'Tis." Dated 1916, in Patterson, it is composed of six verses and is set to what Faiq, the new immigrant, evidently knew as the tune of "My Country 'Tis of Thee," which of course was itself adopted for American use from the British "God Save the King." Faiq's version remains known and sung to the same tune in Tur 'Abdin. ${ }^{24}$ In place of the words "my country, 'tis of thee, / sweet land of liberty, / of thee I sing," Faiq's anthem opens (Poem 4 of the Appendix):

\section{Come all Assyrians}

To prepare a life of goodness for us

With study and knowledge. ${ }^{25}$

A decade after Beth Nahrin's inauguration, in 1926, the magazine published Naum Faiq's Syriac poem "Nineveh and New York," the last Syriac verse of his dealt with here. Faiq was to die only a few years later, at the beginning of 1930.

\footnotetext{
23 Naum Faiq, The Book of Anthems for Wakefulness (Paterson, 1917), 9.

24 I was told this in personal conversation with a well-educated man from Tur 'Abdin; it was confirmed by a second.

25

Faiq, Anthems, 12.
} 
Naum Faiq's 1909 poem is written in a heptasyllabic metre, in two monorhymed strophes with a refrain. What distinguishes it quite clearly from the most familiar poetry in the earlier Syriac canon goes to the core of what makes the "Assyrian Awakening" distinct in its language's history, which is of course its fixation on an ethnic nationalism among communities of the Syriac-language tradition. Faiq, well-educated enough in Arabic to write his own poetry in that language, was thoroughly familiar with the last fifty years of literary revolution that had swept the Arab world, in the period now known as the Nahda, or the "Awakening." So-called literary societies, often secret and driven in large part by Christian Arabs, cropped up across Ottoman Syria in the second half of the nineteenth century. Beirut was the capital of this movement, and the Arab world's first literary society was founded there in 1847 , within its ranks one of the era's most brilliant thinkers, Buṭrus al-Bustānī. Bustānī should be mentioned here on account of his acting as a sort of reminder of the presence of Syriac learning and literature in these earliest days of Arab nationalism; he was educated in Syriac in the Maronite monastery of 'Ayn al-Waraqa, assisted in the translation of a new Arabic-language Bible using Syriac sources, and attempted to translate verse by Gregorius Bar Hebraeus, the thirteenth-century luminary and exemplary figure of the Syriac Renaissance, into Arabic. ${ }^{26}$ It could be argued that the first stirrings of a Syriac literary revival began here, with the attempt to reintroduce the last great Syriac-language writer to a generation of newly conscious Syrians.

Decades later, Ibrāhīm al-Yāzijī, son of another illustrious member of Bustānī's Syrian Association for Sciences and Arts, joined another literary society, more explicit in its calls for Arab autonomy than its predecessor. It was there that, in 1878, Yāzijī stood and declaimed the poem that would later become almost synonymous with the Nahda as a whole - "Arise, ye Arabs, and Awake." That poem is an emblem of its time, firmly neoclassical. Its form does not deviate from the qașida of ancient Arabic tradition, but, as Mustafa Badawi observes, this hardly precludes the modernity of the neoclassical poem as a genre, least of all as regards its intentions and intended audience:

26 Ignatius Afram Barsoum, The Scattered Pearls: A History of Syriac Literature and Sciences, Trans. Matti Moosa (Piscataway: Gorgias Press, 2003), 34; Butros Bustani, 1876. "Ibn alIbri," in Da'irat al-Ma'arif. Qamus 'amm li-kull fann wa-matlab, edited by Butros Bustani (Beirut, 1876-1900), 594ff. 
Within the formal and stylistic limitations of the qasidah the neoclassical poets managed to give adequate expression to their modern problems and preoccupations. At their hands the role of the poet was considerably changed. The poet as the craftsman who was prepared to sell his wares to the highest bidder, or who vied with his fellow craftsmen in verbal acrobatics and display of stylistic ingenuities, as was indeed the case before the modern revival, was gradually but unmistakably replaced by the poet as the spokesman of his community. ${ }^{27}$

Those earliest Arabic literary societies remained somewhat isolated, and it was not until after the restoration of the Ottoman constitution in 1908 that "an extensive network of associations, parties, secret societies and clubs working for reforms and administrative decentralization," ${ }^{28}$ closely associated with the independent press, truly began to develop, and even then the movement's greatest expansion did not come until after 1913.

The context suggests that Naum Faiq's work, and the Assyrian Awakening at large, is more than simply an isolated revival of Syriac-tradition culture. It is quite clearly a beneficiary of the late-Ottoman Arabic cultural revival whose roots lay in the half century before his birth, and which itself, through the persons and works of its Christian standard bearers such as Bustānī, bore natural association with the Syriac-language traditions of geographic Syria. The al-Intibāh society of 1909 is distinguished by its Syriac-tradition membership and emphasis, but only as one of the myriad and predominantly Arabic-language societies working for reform and autonomy across Ottoman Syria; indeed, if found in a list of contemporary societies, it would even blend completely into the mass by its use of an Arabic-Turkish, rather than Syriac, name. At the same time, the al-Intibāh magazine itself remained written in Turkish Garshuni. The society announced that one of its main goals was to reestablish the grammar school that had been shut almost twenty years earlier; ${ }^{29}$ a worthy goal, to be sure, but not one to be understood as more especially urgent in 1909 than in 1907. It was rather the spirit of the times that reignited the old fire.

Faiq took inspiration from the earlier Nahda societies in creating his own. As an Arab Awakening had been declared by al-Yāzijī, so would an Assyrian

27 M.M. Badawi, Modern Arabic Literature and the West (London: Ithaca Press, 1985), 105.

28 Rashid Khalidi, "Abd al-Ghani al-'Urasi and al-Mufid: the Press and Arab Nationalism before 1914," in Intellectual Life in the Arab East, 1890-1939, edited by Marwan R. Buheiry (Beirut: American University of Beirut, 1981), 42. 
Awakening need its own auspicious announcement. Once again, though, it was a spark provided by the Arabic example to light an Aramaic flame. Al-Yāzijī looked back towards the classical Arabic tradition for the model for his ode and entirely naturally, since, as Badawi puts it, "there was no other idiom available" to the neoclassical Arabic poet; ${ }^{30}$ Faiq chose as his model a simple song in Ephremite metre, but rhyming in the long-enduring, Arabic-influenced style of poets since before the Renaissance. Put differently: where the 'idiom available' to the Arab revivalist is the long ode, the Syriac revivalist finds the hymn.

Despite the initially optimistic tone of Faiq's "Arise, Sons of Assyria, Arise" (Poem 1 in the Appendix) in its call for positive change, a closer reading betrays an urgency quite removed from the output of the Arab movement. This is apparent even the Arabic name of Faiq's society; rather than the sense of reawakening from a slumber implied in the idea of a "Nahda," "Intibā $h$ " suggests the wakefulness expected of a watchman. The same sense imbues line 6 , where "refuge" is to be found in irutho, wakefulness, vigilance, the kind of watching the angels on guard in the heavens take part in. ${ }^{31}$ Indeed, in the entire poem, only one line, line 7 , offers a truly positive view of the Syriac community's future: "We shall speed towards exaltation." Line 2 notes the enlightenment of the rest of the world, but only to draw attention to how quickly the chance to join that enlightenment is slipping away. Neither was the concern unwarranted: the Syriac Orthodox Faiq and his coreligionist colleagues had been warned, by the Syriac Orthodox Patriarch himself, against "movements which trespass on Ottoman sensitivities, matters such as composing music ... movements like those which imitate the Armenians, who demand independence."32 In 1912, due in no small part to his publications and public advocacy for his Assyrian cause, Faiq himself was forced to flee the Empire. In 1915 the Sayfo began, the series of genocidal massacres of Syriac-tradition Christians in Ottoman territory. Faiq's hometown of Diyarbekir saw some of the worst devastation.

There's little surprise, then, that the first poem published in Faiq's new American journal, Beth Nahrin, in 1916 deals with the devastation head-on (Poem 2 in the Appendix). Written not by Faiq but by Sharko Ahro, this poem, beginning "Someone give me wings ...," is certainly more lyrical in nature, but remains an address, both to its readers and explicitly to those still suffering back in the homeland in the aftermath of the Sayfo, which means "sword"

30 Badawi, Modern, 102 - here speaking specifically of the poet Mahmoud Sami al-Barudi, but in terms applicable to neoclassicism as a whole.

31 J. Payne Smith Margoliouth, A Compendious Syriac Dictionary (Oxford: The Clarendon Press, 1903), 412. 
in Syriac: "Nor have the sons of vipers yet sheathed the sword of savages." Arranged into four stanzas of four lines each, it is written in the Serughian metre and with a monorhyme in each stanza. This had been a favoured style of Syriac poets since the time of the Syriac Renaissance, 6oo years earlier. And little to nothing has changed - now, in New Jersey, a poet appears, writing as a part of a tradition whose style and form seems in many ways to have remained the same through all that time.

A weak anaphora connects the beginnings of the first three quatrains, each interpretable as a plaintive "O!", and a not-overbearing mirroring effect further links the first two quatrains in particular. Note, for instance, how "to fly" appears in two different forms in lines 1 and 5 . Some mournful wordplay seems to occur in the second line, conflating one pronunciation of "Assyrian" with the Syriac word assuroyo, which means "shackled" or "imprisoned." It is worth noting that popular usage of Othuroyo as a self-designation, following both recent European usage and the long-established Armenian word for Syriac speakers (Asori) was a very recent trend; Following others, Adam Becker gives 1897 as offering "the first explicit claims that the Syrians [Syriacs] were descendants of the ancient Assyrians." 33 This evidences common use only in the years before World War I, especially among intellectuals in the Church of the East. ${ }^{34}$ The popularly accepted etymology, followed also by Syriac scholars and clergy, traced the original name Othuroyo, through a series of consonantal mutations and deletions, to Osuroyo and eventually to Suroyo. ${ }^{35}$

To address his lament to the bnay gensan - Sons of our Nation - and specifically to include Persia alongside Bethnahrin, in parallel stanzas, suggests that, in the midst of ongoing turmoil throughout the Middle East, Ahro is consciously casting his net as wide as he can.

Someone give me wings that I can fly to Bethnahrin

And see my imprisoned Assyrian brothers wherever they are scattered ...

Oh, if only I had wings to fly to that foreign country,

That I could go and dwell upon the heights and the mountains of Persia

$\cdots$

O sons of our nation, oh, we are shattered at your torment.

33 Becker, Revival, 258.

34 Aaron Butts, "Assyrian Christians," in Companion to Assyria, edited by Eckart Frahm (Malden: Wiley Blackwell, 2017), 603.

35

Becker, Revival, 318. 
The entire journal is handwritten. This poem appears in a different hand from the masthead and other articles, its script and vocalization indicating an Eastern origin. It is not implausible that the author was from the Church of the East himself; at the very least he suggests a sense of kinship with his fellow "Assyrians," regardless of where they fall in the centuries-old sectarian divisions. Certainly Faiq, as the publisher, viewed the ethnic unity of the "Assyrian nation" as a simple fact, and their future political unity as a matter of paramount importance. As early as six years before, in an article in Kawkab Madenh̆o, Faiq spoke of

this people which derived from the stock of those once worthy names Asuri and Arami and which later split into five groups - the Suryani, Nestorians, Chaldeans, Suryani Catholics and Maronites - out of ignorance and zealotry. ${ }^{36}$

Even more unambiguous was Faiq's mission statement for Beth Nahrin itself, published with the magazine's inauguration in 1916, and so nearly side-by-side with the poem under consideration:

Our goal is not to show how learned we are, but to serve our vatan [motherland]... for all brothers of the Süryani to come together under a single umbrella. These brothers are Nestorians, Chaldeans, Maronites, Catholics, Protestants ... I remind these groups that their past, their race, their blood and flesh, their tongue, their vatan are all that of the Süryani ... we must work to exalt the name of the Assyrians. ${ }^{37}$

In that context, then, and even regardless of the author's actual provenance, this poem, not only in its content but even in its presentation - markedly different from that of the articles around it - is itself a quiet testament to how important the idea of unity was for Assyrianists of the age, unity among all inheritors of a perceived Assyrian heritage.

Returning to Faiq's poetry, the "anthems" of his Book of Nationalist Songs, seems slightly jarring after the intensely emotional lament of Sharko Ahro's poem in Beth Nahrin. For the first three poems we anticipate an obvious explanation: we could certainly expect a nationalistic poem written in 1916 to have a somewhat bleaker tone than those written a decade earlier. Strangely,

36 Atto, Hostages, 277 (translations and formatting hers).

37 Ibid., 281 (translations and formatting hers). 
though, "My Country 'Tis" (Poem 3 in the Appendix), dated 1916 in the manuscript, does not seem at all to differ in tone from Faiq's famous 1909 hymn. The fifth verse is nearly a paraphrase:

Awake, awake, Othur,

And tear down the walls of ignorance, heroically.

You have had enough of meekness and of carelessness,

And this will forever be the cause of your destruction.

Even more striking is the sixth and final verse:

So who will give me wings to fly to Bethnahrin?

To find rest in its soil, and smell its scent,

To trade in imperishable delights for myself.

As mentioned above, Ahro's poem was published at the beginning of 1916 - so it seems highly implausible, to say the least, that Faiq did not at least have its repeated opening line in mind when he wrote this. The tone of his indebted poem could not be more different, though. Ahro begs for wings to fly to a devastated country and offer his compatriots aid, of whatever sort he can; Faiq is retreating on the wings of poesy and beer-hall melody to a kind of imagined paradise lost, an (only recently!) exiled homeland idealized by nostalgia. In the midst of wartime, and in comparison to Ahro's heartfelt lament, the result can feel a little bit trite. Nothing in the previous verse - or anywhere in the anthem - really corrects the nagging sense of insufficiency-in-context.

Faiq's admonitions and rallying cries to his fellow "Assyrians" are very consistent in their content. The "Assyrian Nation" has spent too long cowering in ignorance, and darkness of mind and spirit; it has failed to assert its claim to the patrimony of its homeland, or its intellectual and cultural inheritance; it has "fallen asleep" and, to the extent that it has begun to awaken, it has done so thus far only drowsily, listlessly, aimlessly. The third song in his manuscript, entitled simply "Assyrians," does little but repeat the theme in a different metre, namely that of the mournful incense hymn (Poem 5 in the Appendix): $: 3$

38 The document itself gives the melody as "to the Incense Hymn," which is used in mourning rituals in the Syriac churches. 


\author{
Oh Athuroye \\ For in our hands remains \\ Our treasure is scattered \\ And the people
}

At the beginning of time

And today we wallow

Our shining motherland

And today the sons of our Nation

Sons of pagans rule

And have sapped the strength awake from sleep

not a hair from the head

and our splendour is destroyed

has become enslaved again to strangers

we were the possessors

as servants and the disinherited

is Bethnahrin

are scattered from it

in our rich land

of our powerful Nation

Although this poem, like the next two poems, probably dates to the original 1908 publication of Faiq's collection of anthems, there is little evidence in the text itself to suggest whether the poem belongs closer chronologically to "Awake, Sons of Assyria, Awake," or to the post-exilic, post-Sayfo "My Country 'Tis." In none of these poems is there a real call to arms, nor, in fact, a real recognition of the immediate mortal plight of his people. Consider "Assyrians" in contrast to Ahro's distinctly post-Sayfo poem. The people are "enslaved" and "disinherited," rather as the ancient Israelites - but they are not "tormented" by the "dagger of Beelzebub" or the "sword of savages." The "sons of vipers" of Ahro's lament are here only "sons of pagans," illegitimate rulers rather than murderers. "My Country 'Tis," (Poem 4 in the Appendix) outlines the trouble: the manuscript's second poem (Poem 6), "Wakefulness," has already provided the solution.

When wakefulness advances

Among the people of the Suryoye;

And all the weapons of teachings also

Rise in place of illiteracy

And our language of the forefathers is eagerly read

And our Nation knows and strives again with the other peoples

Then, as equals we shall shout

Long live wakefulness

For Faiq, the plight of his people is essentially a spiritual illness, no matter what very real, physical suffering is visited on them by history or its human 
agents. Their salvation, therefore, is likewise a spiritual concern, the cause of Assyrian nationalism one to be fought for in the mind and soul, through education and upbringing. As an individual striving for greatness must rouse himself daily from the stupor of sleep, instead of lazing in bed; must approach his set tasks with discipline and diligence, instead of going only haphazardly about them; must always be attentive to the changing world around him, learning from it and bettering himself; so too must a community do the same, acting as one body, in order to achieve greatness and true parity with the communities around it. This is Faiq's exhortation to his people no matter where he is, whether in 1908, in Diyarbekir, or nearly a decade later, in Patterson: awaken, and see and strive, rather than arise, and fight.

Awakening - the root / wr/ "to wake, to watch, being awake" - is unmistakably the tonic key of all Faiq's nationalist thinking, unchanged in Patterson from the secret society in Diyarbekir. Of the five remaining poems discussed here, all of them save "Nineveh and New York" use the root in some variation. Often, as above, this comes as a noun, 'irutho as wakefulness, or watchfulness, or vigilance; sometimes as a command - ett ir; but regardless, the implication, in the whole of Faiq's oeuvre, is not simply the state of being not-asleep, but of being actively conscious, watchful, vigilant. The same root is used for the name of the class of angel translated as "Watcher." Of course the corresponding root /qwm/ "to rise" is used widely as well, but clearly in the sense of rising from sleep, and that root, more clearly a verb of movement, isn't quite as ubiquitous as "waking."

Language, metaphor, and imagery related to this central theme of 'waking' is encountered everywhere, but it reaches its peak in the most self-consciously 'literary' poem dealt with here: "A Plea and a Rousing Cry" (Poem 3 in the Appendix). Written, like Ahro's poem in Beth Nahrin, in the Serughian metre an immediate indication of its primarily literary rather than musical intent, as opposed to the primarily hymnal metres of the previous three poems "Rousing Cry" opens with some genuine if somewhat overbearing wordplay, which mostly serves to drive the thematic point home for us as observers a century later.

Watcher who awoke in the heart of the watchers this watchfulness, Awaken in us, Lord, brotherly love and harmony, And bring light to the eyes that are blinded in negligence, And help all of us to labour in the vineyard in eternity.

Already in this first stanza we notice an element missing in the other poems namely, that of religion. It is quite telling that Faiq's most intentionally literary "nationalist song" is also the poem most steeped in Christian imagery (and this 
despite his heavy use of hymn meters!). These elements all come together in strophe 5 , quoted earlier in this paper:

Oh Suryoye, stinking in the grave like Lazarus,

Rise, for Christ cried out "Awake, and there shall be hope for you."

The monition to awaken is now a divine command as well - the secular cause of the nation given heavenly impetus, put into the Messiah's own mouth. Of all the material dealt with here, the marvellously cavalier image of the nation as a stinking corpse in a dark grave is certainly Faiq's finest.

As suggested by the Lazarine grave, a natural accompaniment to the central theme of wakefulness is the contrast of darkness, and blindness, with that of enlightenment, and sight:

\section{Bring light to the eyes that are blinded in negligence}

...

Oh Suryoye who slept and turned from knowledge

Rise from the sleep of negligence and see the nations

...

Our lantern shall not be lit, which has been extinguished in laziness, And we shall dwell forever in darkness and in misery

The theme is not exclusive to this poem, but is found also in "My Country 'Tis" (Poem 4, s. 4): "Why does darkness rule always in our eyes and gloom rule always in our mind?" and in "Awake" (Poem 1, s. 2): "And see how enlightened the world is."

Certain other themes and key words reveal Faiq's conception of the Assyrian nationalist cause. Once awoken from sleep, the national body must be "diligent" and "disciplined" in its study and self-formation; the first focus of study must be the material of the nation itself, its language, history, inheritance, and moral teachings. Strophe 5 of "Rousing Cry" (Poem 3 ) ties the curriculum once again to the image of enlightenment:

Be diligent as you study the teachings of the first who passed They shall shine a light for you like that of daybreak.

The poem elsewhere warns of the consequences "if we don't stand today in diligence" (hattifutho, l. 11), while trumpeting that "through watchfulness we shall arrive to the stair of diligent success" (kashshirutho, l. 13). "Watchfulness" (Poem 6) lionizes both "all the weapons of teachings" (1.3) and "our language of the forefathers" (l. 5); in "Assyrians" (Poem $5,1.5)$ the current state of slavery 
is contrasted with how "at the beginning of time / we were the possessors". "My Country 'Tis" (Poem 4) is the mother lode. Strophe 4 gives us:

Come let all of us be diligent and carry in our heart

The splendour of our forefathers and glory of our kings

Strophe 3 has already expanded on those "kings," bringing in the pseudomythological side of a historic imagination:

\section{Oh Sons of the race of Aram and Children of Shamiram You shall attain victory and you shall bear sweet fruit If your path is in the footstep of our masters.}

It is important to remember at this point, in conjunction with the religiosity evidenced earlier in "Rousing Cry," that there was no necessary conflict between a celebration of an imagined, glorious pre-Christian past and a deep Syriac Christian identification. If anything, the two had worked in parallel since the inception of Assyrian nationalism, in its earliest stages in Urmia. The Chaldean Catholic Patriarch Thomas Audo, among other things a strident nationalist and formidable scholar whose dictionary of Classical Syriac remains in use, was adamant about the importance of studying the long-hidden history of his people's ancient predecessors, pagan though they were. ${ }^{39}$ Shamiram herself the legendary queen of Nineveh's founding king, Ninos - seems to have been inserted into the Syriac imagination by one Deacon Augustine Thomas, another Chaldean, in a 1898 article for the nationalist-inclined Urmian newspaper Voice of Truth. ${ }^{40}$ As expected from the use the Serughian metre, there is a bit more in the way of formal craft to mine in "Rousing Cry" than in Faiq's other verse. One of the best-crafted lines is the first in strophe 4, with full parallelism across the first two pausae that not only grants us an internal rhyme but a full assonantial repetition:

ayko shufran, ayko 'utran, o bnay Orom

Where is our beauty, where is our opulence, O Sons of Aram?

The chorus-like repetition of " $u$ Suryoye" at the beginning of strophes 2, 5, and 7 lends a sense both of balance and movement to the poem as whole. More importantly, though, it serves to highlight yet again the easy fluidity of national identity in Faiq's mind, and in the public consciousness of many of his

39 Becker, Revival, 321.

40 Ibid., 319. 
contemporaries. Suryoye, Athuroye, sons of Aram - all coexist in the mythmaking imagination of the nationalist poet. All are connected by the shared traditions of language, religion, culture and ancient history, even if certain of these traditions receive more spotlight in one or another poem.

Just as "Rousing Cry" emphasizes the religious tradition of the shared Suryoyo identity, "Nineveh and New York" (Poem 7), published a decade later, clearly emphasizes its secular, historical tradition. The metre is the same, Serughian, but the poem is divided into rhyming distiches rather than quatrains:

\section{I have met two finely fashioned cities in the world:}

I cannot form the figures sufficient to praise them.

One is placed in the East in the midst of rivers:

The other in the West is mother of beloved things.

One has all of Bethnahrin surround it from two sides

And the other is surrounded by the Hudson river at all approaches.

One is built upon dry land with ten thousand wonders;

The other sits in the midst of the sea and its surroundings are marvellous.

Two sisters lording over beauty and ceremony

From whom the world has drained the draught of teaching.

Their names, if you wish to know them written:

Nineveh and New York, wreathed with splendours that fill them with beauty.

The poem, technically speaking, is so unexceptional that it seems fairest to treat it as a teaching poem - something intended for young readers, in the vein of the esteemed Malfono ("Professor") Qarabash (1903-1983), whose short lessons and textbooks have educated generations of young Syriac readers. The content of the poem, however, is instructive to us, even if - and perhaps especially if - its primary purpose was more didactic than lyric. It opens as a dry paean to the two eponymous "great cities" of the world, a subject that ought to allow the poet a little more adjectival wiggle room than "great" and "glorious." A sort of ping-pong jingle effect is created by the comparison of the one to the other: "Nineveh is surrounded by two rivers, New York is surrounded by one river; Nineveh was built with engineering, New York was built with discipline," (cf. l. 1-24) and so on. A rather flat-footed use of anaphora through this opening section could be interpreted as having biblical intimations, although after all most things could.

Before the half-way mark has been reached, though, the poet seems to forget the discipline of the comparison purported in the title, and drifts off into an elaboration of the ancient Assyrian capital. Presumably the idea here is to draw an equivalency between the two to the minds of modern readers, 
establishing Nineveh as the true predecessor to the greatness of New York, and of the country as whose greatest manifestation it stands: "The intersections of streets, $\mathrm{O}$, and avenues, and ... high towers and ziggurats," (1. 37; 1. 45) and the young Syriac reader is meant to look across the water at the Manhattan skyline, reading this description of Nineveh, and feel himself the author of these things through his lineage. Even as we flee the homeland, Faiq insinuates to his kinsmen, we flee to nations indebted to us. In the long gridded streets of New York Faiq finds memorial to the streets and processional avenues of Nineveh, beneath their ziggurats instead of skyscrapers. It is worthwhile to note that what we in the twentieth century might consider the most distinctive type of New York architecture, the art-deco style whose ziggurat-like steps and setbacks were in turn essentially legislated into being by zoning ordinance in 1916, would have just been appearing in the decade since Faiq's arrival, and reached an early heyday by 1926. Just as those towers echoed Nineveh's, so too did the city's ordinances and laws; indeed, Faiq, though certainly not referencing any particular New York ordinance, explicitly includes "well-ruled laws, and ordinances" (1. 38) in his catalogue of great aspects of Assyrian heritage, and, importantly if perhaps so astoundingly, wilfully fantastical, "rule of the people" (1. 39)... that is to say, ancient practices, teachings, and doctrines which in his own day are reflected in America's greatness, and which the modern Assyrian nation must pursue with discipline and diligence to regain its ancient glory.

Consider lines 49 and 50. Although until this point the sense of the strophe has already imbued the entire poem, its firm pronouncement in these lines does carry an unexpected power. The two lines are connected by both a sort of anaphora and a pleasant alliterative atmosphere of $/ \mathrm{th} /$ and $/ \mathrm{b} /$. In the second line, rhythm, repetition, assonance (of /i/ and /e/, but not in a grammatical parallelism), and simplicity and directness hit the reader with the weight of truth:

Hiy-(h)i itheyh l-Othuroye athro w-motho

She indeed for the Assyrians is a nation and a homeland.

From this point, there is a strange opening-up of the theme. The "she" in question is not the Nineveh of the title: it is Bethnahrin as a whole. Without any clear reason the poem ends in the enumeration of various pseudo-historical facts about the homeland and the Assyrian heritage, fizzling out in an agreeably brief list of Assyrian kings. Notably, in the list of peoples which forms the ends of lines 53 to 56 , Faiq asserts a relation through Abraham to the Hebrews, and direct relationships between the Assyrians, Chaldeans, and Arameans. By 
this point in his life, Faiq had already started his second American journal, Huyodo - in English, Unity - putting into a masthead one of the central tenants of his Assyrian nationalism.

Whatever the purpose of the poem, and whatever its literary value, its content and context offer a useful touchstone for the question of how to conceive of Faiq's own place as a poet - specifically as a Middle Eastern poet with national identity as his core theme. The malfono arrived in the New York area right at the swell of the decidedly romantic Mahjar movement, the wave of émigré writers and poets most famously represented by the New York-based Pen League and writers such as Khalil Gibran, which represented a sea change in Arabic towards modern literature. ${ }^{41}$ Amin Rihani is composing his prose poetry for Manhattan at the same time that Faiq is writing neoclassical teaching mimre for it. Consider further Ilya Abu Madi, whose second diwan, and first to be written in America, was published with a preface by Khalil Gibran in 1919, and whose third book of poems, considered by critics to contain his most excellent work, came in $1927 .{ }^{42}$ Across the water from Faiq, Abu Madi is giving voice to the tortured individualist, the lone prophet with his inscrutable universal mysteries and endless visionary searching. Compare that to the role of the poet in the pages of Beth Nahrin. He must be first and foremost a representative of, and a leader for, his people. If "Nineveh and New York" is indeed a teaching poem for young readers in the diaspora, it could not testify to his responsibilities better. There is no firm space for purely personal soul-searching and torment in the literature of the Syriac language yet; that is a luxury that first requires some communal safety, stability, and certainty. Thus, Naum Faiq composes no cries to the cosmos, but rather rallying cries to the homeland and its scattered people, urges to self-education and offers tools to aid in the cause. Central to this cause is the language of his forefathers - at one time both the foundation of the national edifice, in dire need of restoration, and the tool to help restore it.

\footnotetext{
41 Badawi, Modern Arabic, esp. 102-109.

42 See Robin Ostle, "Ilya Abu Madi and Arabic Poetry in the Inter-War Period," in Studies in Modern Arabic Literature, edited by R.C. Ostle (London: School of Oriental and African Studies, 1975), 37-39.
} 


\section{Appendix: the Syriac Poems}

1

Awake, Son of Assyria!

Syriac text taken from: Sargon Donabed, Remnants of Heroes: The Assyrian Experience (Chicago, 2003), 53 .

$$
\begin{aligned}
& \text { 1) }
\end{aligned}
$$

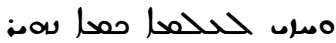

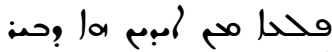

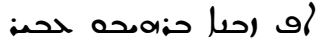

$$
\begin{aligned}
& \text { l2ll }
\end{aligned}
$$

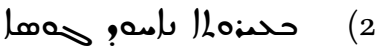

$$
\begin{aligned}
& \text { حمححه }
\end{aligned}
$$

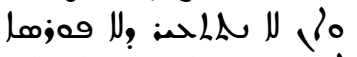

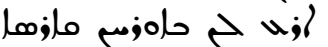

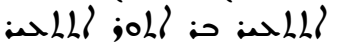

\section{$2 \quad$ Someone Give Me Wings That I Can Fly to Bethnahrin}

The Syriac text comes from the January 15th, 1916 edition of Bethnahrin, accessed at www.AssyrianArchive.org.

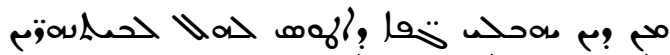

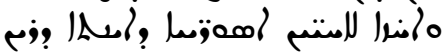

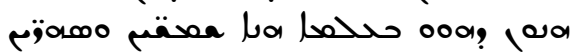

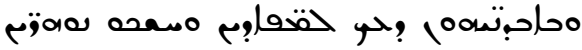

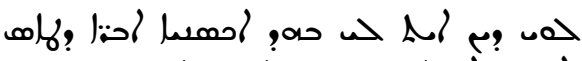

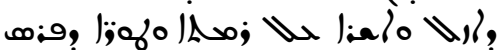

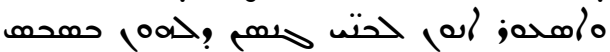

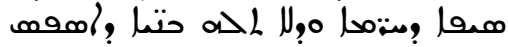

$$
\begin{aligned}
& \text { of }
\end{aligned}
$$

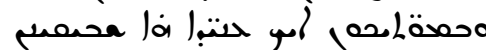

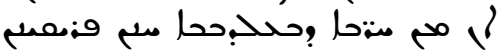

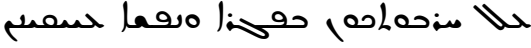

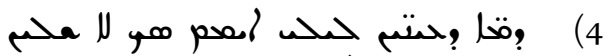

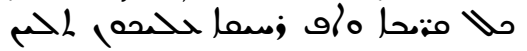




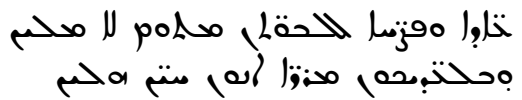

$3 \quad$ A Plea and a Rousing Cry

Source: Naum Faiq, The Book of Anthems for Wakefulness (Paterson, 1917), 8-10.

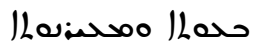

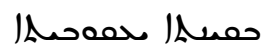

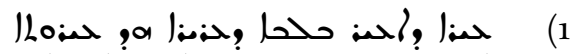

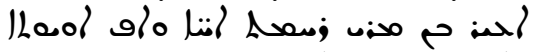

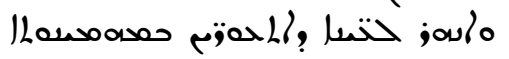

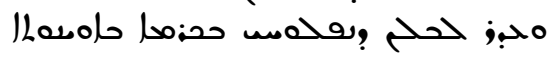

$$
\begin{aligned}
& \text { of }
\end{aligned}
$$

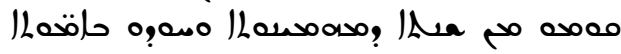

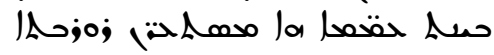

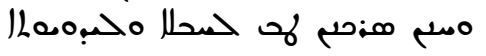

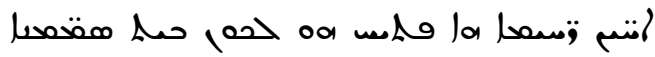

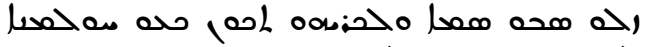

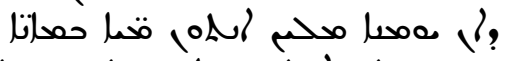

$$
\begin{aligned}
& \text { osa }
\end{aligned}
$$

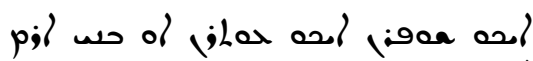

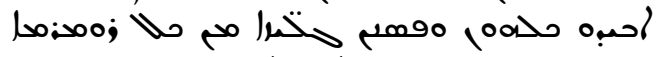

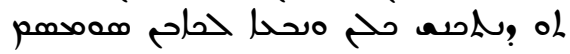

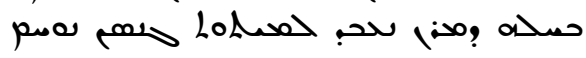

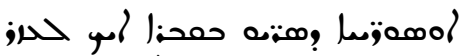

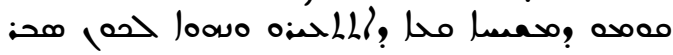

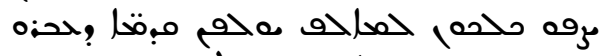

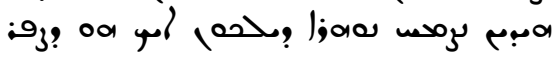

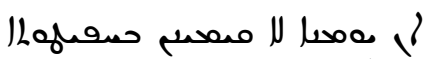

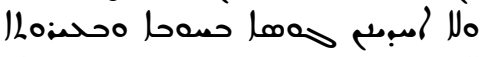

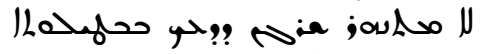

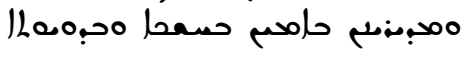




$$
\begin{aligned}
& \text { | }
\end{aligned}
$$

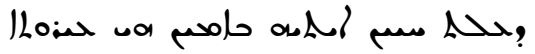

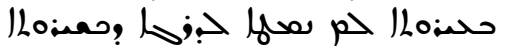

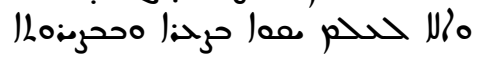

$4 \quad$ My Country'Tis

Source: Faiq, Anthems, 11-13.
lladoof, (1

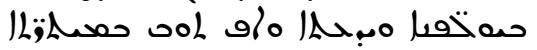

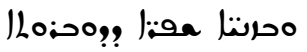

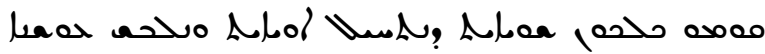

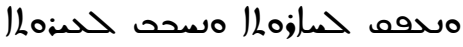
boo,

of

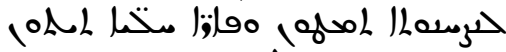

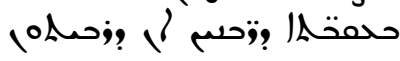

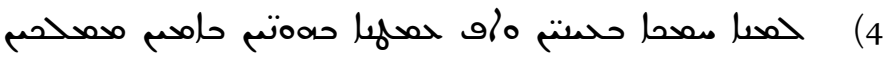

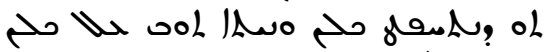
قامها| واحةم محهدصا ومخحم

لماحس

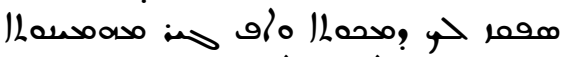
al

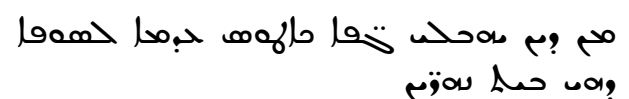

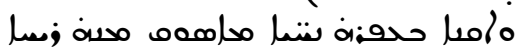

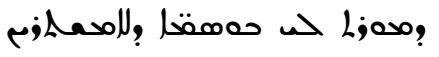


$5 \quad$ Assyrians

Source: Faiq, Anthems, 10-11.

$$
\begin{aligned}
& \text { 1 }
\end{aligned}
$$

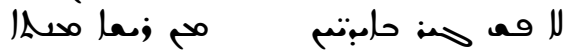

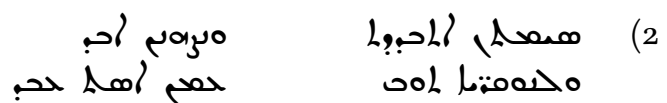

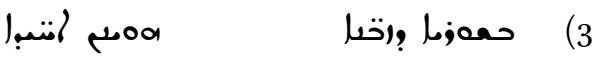

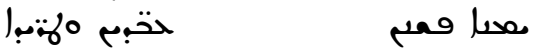




\section{$7 \quad$ Nineveh and New York}

Syriac text accessed as a PDF attachment to the article "Naum Faiqs dikt om Nineve och New York." Hujada, February 5, 2016. Accessed at http://www.hu jada.com/article.php? $\operatorname{ar}=2777 \&$ page $=1 .{ }^{43}$

$$
\text { y;000 0س0 }
$$

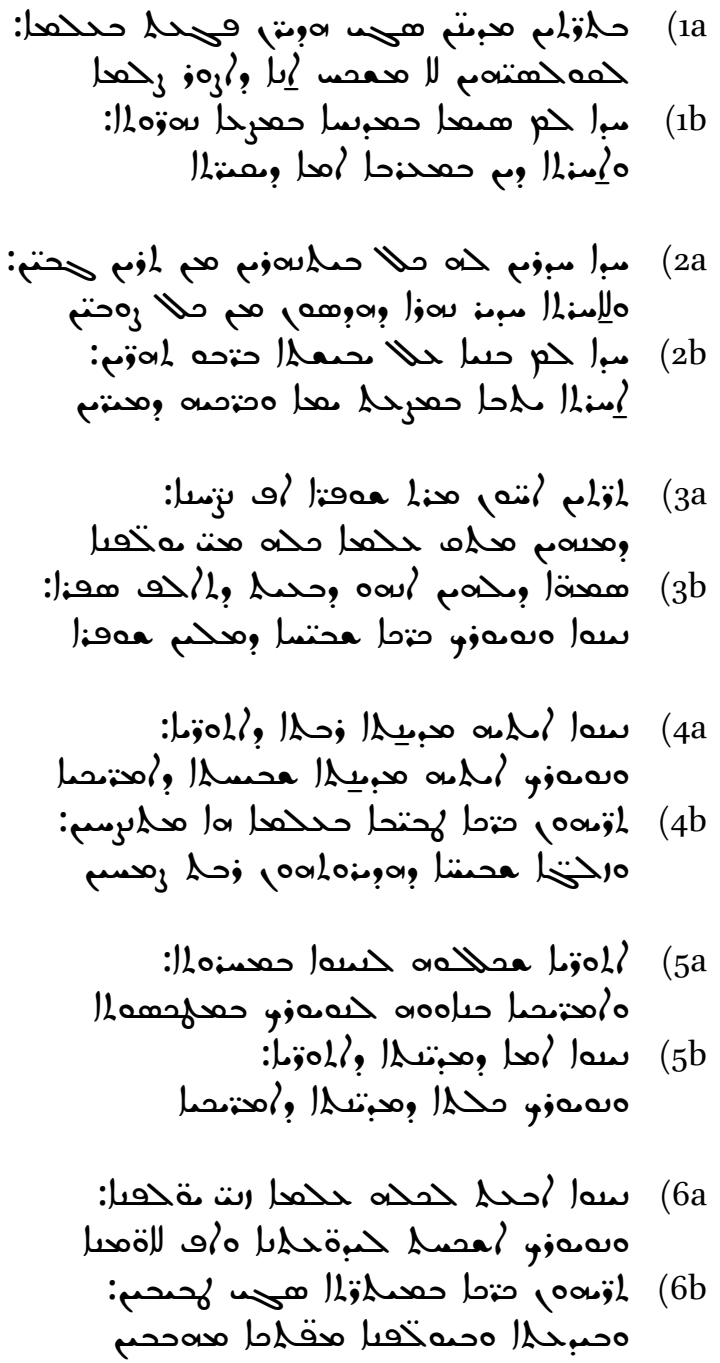

43 Please note that I have retained the formatting as printed in Hujada - that is to say, grouped into quatrains, although the intended division appears to be strophes of two lines each. 
(7a

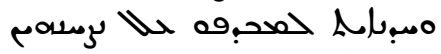
7b

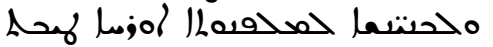

8a

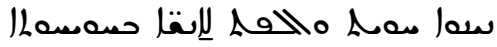

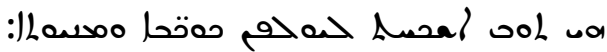

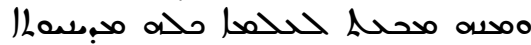

9a

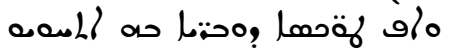
: (9b

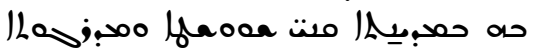

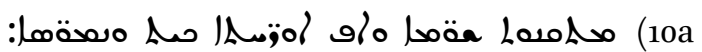

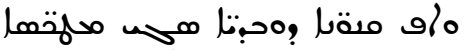

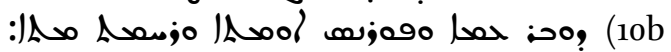

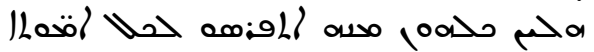

(11a

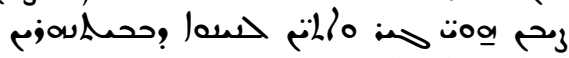

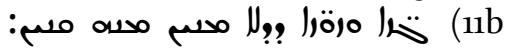

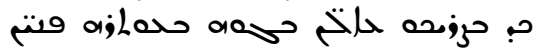

12a

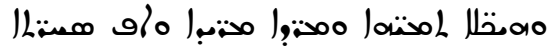
12b

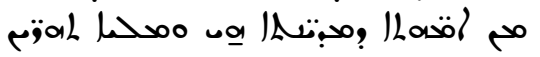

: 13a Asoo (jll b;oll and? wa wa : 13b

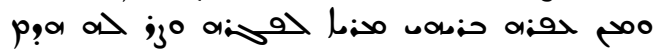

14a

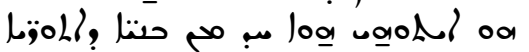
(14b

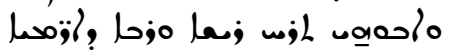




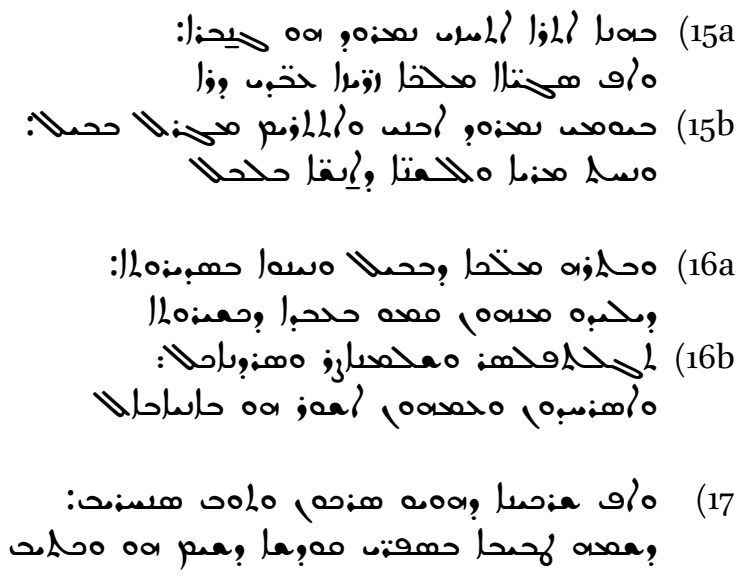

\section{Bibliography}

Akgunduz, Emrullah. "Some Notes on the Syriac Christians of Diyarbekir in the Late Nineteenth Century: A Preliminary Investigation of Some Primary Sources." In Social Relations in Ottoman Diyarbekir, 1870-1915, edited by Joost Jongerden and Jelle Verheij, 217-240. (Leiden: Brill, 2012).

Anonymous. "Naum Faiqs dikt om Nineve och New York." Hujada (February 5, 2016). Accessed at http://www.hujada.com/article.php?ar=2777\&page $=1$.

Anthony of Tagrit. The Fifth Book of the Rhetoric of Anthony of Tagrit. Corpus Scriptorum Christianrum Orientalum 480, edited by J.W. Watt. Leuven: E. Peeters, 1986 (Syriac).

Anthony of Tagrit. The Fifth Book of the Rhetoric of Anthony of Tagrit. Corpus Scriptorum Christianrum Orientalum 481, translated by J.W. Watt. Leuven: E. Peeters, 1986 (English).

Atto, Naures. Hostages in the Homeland, Orphans in the Diaspora: Identity Discourses Among the Assyrian/Syriac Elites in the European Diaspora. Leiden: Leiden University Press, 2011.

Badawi, M.M. Modern Arabic Literature and the West. London: Ithaca Press, 1985.

Baumstark, Anton. Geschichte der syrischen Literatur. Bonn: A Marcus \& E. Webers Verlag, 1922.

Barsoum, Ignatius Afram. The Scattered Pearls: A History of Syriac Literature and Sciences, translated by Matti Moosa. Piscataway: Gorgias Press, 2003.

Becker, Adam H. Revival and Awakening: American Evangelical Missionaries in Iran and the Origins of Assyrian Nationalism. Chicago: University of Chicago Press, 2015 . 
Bethnahrin, January 15, 1916. Accessed at http://assyrianarchive.org/database/Beth nahrin-\%28Mesopotamia\%29-The-Assyrian-Paper/1839/article-detail/.

Bustani, Butros. "Ibn al-Ibri," in Da'irat al-Ma'arif. Qamus 'amm li-kull fann wa-matlab, edited by Butros Bustani, 594ff. Beirut, 1876-1900.

Butts, Aaron. "Assyrian Christians." Forthcoming in Companion to Assyria, edited by Eckart Frahm. Malden: Wiley Blackwell. Accessed at https://www.academia .edu/1587631/Assyrian_Christians.

Coakley, J.F. The Church of the East and the Church of England: A History of the Archbishop of Canterbury's Assyrian Mission. Oxford: Clarendon Press, 1992.

Dinno, Khalid. The Syrian Orthodox Christians in the Late Ottoman Period and Beyond. Piscataway, Gorgias Press, 2017.

Donabed, Sargon. Remnants of Heroes: The Assyrian Experience. Chicago: Assyrian Academic Society Press, 2003.

Faiq, Naum. The Book of Anthems for Wakefulness. Paterson: 1917.

Khalidi, Rashid. "Abd al-Ghani al-'Urasi and al-Mufid: the Press and Arab Nationalism before 1914". Intellectual Life in the Arab East, 1890-1939, edited by Marwan R. Buheiry. Beirut: American University of Beirut, 1981.

Kiraz, George A. "Fāiiq, Na"ūm." In Gorgias Encyclopedic Dictionary of the Syriac Heritage, edited by Sebastian P. Brock, Aaron M. Butts, George A. Kiraz and Lucas Van Rompay, https://gedsh.bethmardutho.org/Faiq-Naum.

Macúch, Rudolf. Geschichte der spät- und neusyrischen Literatur. Piscataway: Gorgias Press, 2009.

Margoliouth, J. Payne Smith. A Compendious Syriac Dictionary. Oxford: The Clarendon Press, 1903 .

Mengozzi, Alessandro. Religious Poetry in Vernacular Syriac from Northern Iraq (17th-2oth Centuries): An Anthology. csco 628; Leuven: Peeters, 2011.

Murre-van den Berg, Heleen. "A Syrian Awakening: Alqosh and Urmia as Centres of Neo-Syriac Writing." In Symposium Syriacum viI, Uppsala University, Department of Asian and African Languages, 11-14 August 1996. Edited by R. Lavenant, S.J., 499-515. Orientalia Christiana Analecta 256, Rome, 1998.

Murre-van den Berg, Heleen. From a Spoken to a Written Language: The Introduction and Development of Literary Urmia Aramaic in the Nineteenth Century. Leiden: Nederlands Instituut voor het Nabije Oosten, 1999.

Murre-van den Berg, Heleen. Scribes and Scriptures: The Church of the East in the Eastern Ottoman Provinces (1500-1850). Eastern Christian Studies 21, Louvain: Leuven: Peeters, 2015.

Ostle, Robin. "Ilya Abu Madi and Arabic Poetry in the Inter-War Period." In Studies in Modern Arabic Literature, edited by R.C. Ostle (London: School of Oriental and African Studies, 1975). 
Sheehi, Stephen. "Towards a Critical Theory of al-Nahdah: Epistemology, Ideology and Capital." Journal of Arabic Literature 43 (2012), 269-298.

Sprengling, Martin. “Antonius Rhetor on Versification.” Chicago: University of Chicago Libraries, 1916.

Taylor, David G.K. “Your Sweet Saliva is the Living Wine': Drink, Desire, and Devotion in the Syriac Wine Songs of Khamis Bar Qardahe." In The Syriac Renaissance, edited by Herman Teule and Carman Fotescu Tawinkl, 31-51. Leuven: Uitgeverij Peeters, 2010. 